INTERNATIONAL JOURNAL OF RESEARCHES IN BIOSCIENCES, AGRICULTURE AND TECHNOLOGY (c) VISHWASHANTI MULTIPURPOSE SOCIETY (Global Peace Multipurpose Socie ty) R. No. MH-659/13 (N) www.vmsindia.org

\title{
ENVIRONMENT AND CLIMATE CHANGE; RESPONSIBLE FACTORS FOOD SECURITY ISSUES IN DROUGHT PRONE AREA: BEED DISTRICT.
}

\author{
Chetana V. Donglikar ${ }^{1}$ J. J. Kshirsagar ${ }^{2}$ and R. G. Machale ${ }^{3}$ \\ 1Dept. of Home Science, Kalikadevi Arts Commerce \& Science College, Shirur (ka.) Dist. Beed. \\ ${ }^{2}$ De p- Botany, P.V.P. College, Patoda Beed \\ ${ }^{3}$ K.S.K. College Beed \\ crabarshikar@gmail.com
}

\begin{abstract}
:
Water resources management is one of the most important challenges the world faces. We are drinking, irrigating, and using wate $r$ faster than precipitation can replenish groundwater. Demand for water resources of sufficient quantity and quality for human consumption, sanitation, agricultural irrigation, and manufacturing will continue to intensify as populations increase and as global urbanization, industrialization, and commercial development accelerates. In last few years, climate change is a major challenge for agriculture, food security and rural livelihoods es pecially in Marathwada region of Maharashtra. Marathwada is facing worst years of droughts in last three years. Agriculture is the sector most vulnerable to climate change. The dry areas like Marathwada are also challenged by rapid population growth, frequent droughts, high climatic variability, land degradation and desertification, and widespread poverty. Food insecurity, poverty, and poor access to natural resources also manifest themselves in conflicts which have been concentrated in regions heavily dependent on agriculture. In Beed district of Marathwada region 24.47\% pe ople are dependent on agriculture. Climate issues has gone up with shortage of drinking water supply and electricity, frequent droughts, failing crops and suicide of farmers, une mployment, corruption and increasing crimes. Crop pattern is as follows: wheat $961 \mathrm{Kg}$, Jowari $723 \mathrm{~kg}$. Bajri $838 \mathrm{~kg}$. Cereals -Harbara(Chana) $403 \mathrm{~kg}$, tur $381 \mathrm{~kg}$, Ground nut $789 \mathrm{~kg}$. Cotton(L.T.) $552 \mathrm{~kg}$, and all these are less when compared to the state production and proportion therefore keeping behind regional disparities in conce $\mathrm{m}$ to Beed district's economic, agricultural, social, industrial and human resource development in present scenario, which indicates major concern

Key Words: Food Security, Drought in Marathwada, Climate Cange and Food Security
\end{abstract}

\section{Introduction:}

In most developing countries, land-andwater-based occupations consisting of crop husbandry, animal husbandry, fisheries and forestry are the major sources of employment and income in rural areas. In this context, agriculture assumes a more significant role in the development of national and global food and nutrition security systems than just being the source of food. Therefore, in predominantly agricultural countries, importing food would have the additional conseque nce of enhancing rural unemployment, when this is done to compensate for inadequate national attention to agricultural development. Thus food security has to be viewed in the contexts of food production, job creation and income generation. An additional is sue of ove rriding importance, if we are to ensure that today's progress is not at the expense of tomorrow's prospects, is that of conservation of the ecological base for sustained agricultural production. The various issues relating to the sustainable production of food for the growing population have been dealt with by the Panel on Food Security and Environment, of the World Commission on Environment and Development (1).
In last few years, climate change is a major challenge for agriculture, food security and rural livelihoods especially in Marathwada region of Maharashtra. Marathwada is facing one of the worst droughts in the past 40 years. Reports say that last year, severe droughts had prompted people to migrate to Mumbai and neighboring states of Gujarat, Karnataka and Andhra Pradesh from 3,905 villages in 12 districts of the state Districts of Ahmednagar, Aurangabad, Jalna, Beed and Osmanabad were reported to have only enough drinking water reserves. Impending summer had worsen the situation and for nearly half year the state was transporting water from neighboring districts and even by trains from other states.

Agriculture is the sector most vulne rable to climate change due to its high dependence on climate and weather and because people involved in agriculture tend to be poorer compared with urban residents. Agriculture is part of the problem and part of the solution. Food security and livelihoods depends on sustainable agriculture. Achieving food security requires adequate food availability, access and absorption. Agriculture plays a vital role in contributing to all the three components of food security 
Over time, the nature of agriculture has been changing. There has been diversification in cropping patterns from traditional cereals towards high value products such as Sugarcane, cotton vegetables, fruits, flowers. Rural areas rely on the agriculture sector for their livelihoods. As such, agriculture provides a safety net for the poor. Increasing demand for food and industrial crops has intensified agricultural production and competition for land and water resources. Much of the region's growth is also dependent on natural resources. Population is going to increase further and with rising demand for food which in turn puts additional pressure on sustainable food production.

Food security is defined by FAO as the physical and economic access to food for all people at all times (2) has pleaded for enlarging this concept into one of Nutritional Security, since only access to balanced nutrition and safe drinking water can ensure that every child has an opportunity for the full expression of its innate genetic potential for physical and mental development. The widespread hunger prevailing in many nations of the world is not due to the non-availability of food in the market but is due to the lack of adequate purchasing power among the rural and urban poor. Inadequate purchasing power in its turn is due to insufficient opportunities for gainful employment. The famines of jobs and of purchasing power are becoming the primary causes for the famines of food in the households of the poor.

\section{Negligible background of Beed district of} Marathwada:

Beed has a long history as a neglected and backward are a with a negligible growth. In 1997 Sharma committee has listed Beed as one of the 100 most backward districts in India. $(\mathbf{3}, \mathbf{4 , 5 )}$ Industrial and economic backwardness, lack of good transport facility, electricity and literacy were the issues in 1960s and they are the same even today.(3,6) Without proper arrangement of water supply and transport facility, this declaration resulted nothing.

Economic backwardness is attributed to the lack of natural resources, frequent droughts, lack of good transport facilities and corruption.(3)Economy entirely depends on monsoon dependent agriculture, service sector and small businesses. As per censes 2011 , from overall population $24.47 \%$ people are dependent on agriculture and $14.67 \%$ on agricultural labour. Remaining of the total population is engaged in nonagricultural works .Beed is one of the poorest distric ts of Maharashtra with Per capita GDP of Rs 15,303 (about \$380) which is lower than the Maharashtra State average GDP Rs 17,079 (about \$427) (3,6)

Social and environmental issues are no different than that of the whole country. Human rights (especially women's and children's), child labor, poverty, rising HIV infections, religious strife, human trafficking and sexual abuse $(9,10,11,12)$ are some major social issues of concern in Beed. Sex Ratio in the town is also on decline as is the case of the whole country due to foeticide of female babies. The $d$ istrict ranks 143rd in literacy in India based on IndianNgos.com research and analysis of 586 districts throughout India.(7,8) On Human Development Index (HDI), using UNDP method, Beed ranks 18 th out of 30 districts in the State of Maharashtra, with $0.47 \mathrm{HDI}$. It is 7 th poorest district in the state with Human Poverty Index (HPI) of $21.21 .(5)$

\section{Climate of Beed district:}

In the recent times the list of is sues has gone up with shortage of drinking water supply and electricity, frequent droughts, failing crops and suicide of farmers, unemployment, corruption and increasing crimes.(3). The climate of Beed district is hot and dry. Summers are very long ranging almost five months from mid February to June. Natural water sources get dry by the end of November-December. Rains are scarce and occur only during the monsoons from July to Septe mber. Humidity is low and winters are dry. Soil is coarse and rocky with low vegetations and forests. Due to inadequate monsoon, the underground water level has reached 300 feet down and the problems are complicated. Deforestation, desertification, frequent droughts, shrinking water reservoirs and extreme shortages of drinking water, especially in rural areas are major issues which needs urgent attention.

\section{Agriculture and Food security:}

There is an important role of agriculture sector in providing livelihood to a large number of people in the rural areas. The Asian economies along with the world economy experienced one of the worst food crises with prices of major grains and other food products rising sharply and pushing more people toward poverty and extreme hunger. To those already daunting challenges, climate change adds further pressure on agriculture adversely affecting the poor. In such conditions issue of food security be comes a matter of challenge.(14) 
According to Food and Agriculture Organization (FAO), food security exists when all people, at all times, have physical and economic access to sufficient, safe, and nutritious food to meet their dietary needs and food preferences for an active and healthy life. Food security consists of mainly four elements, viz. availability, accessibility, sustainability and utilization (Table 1).

\section{Availability:}

Food availability has been estimated based on per adult food supply through agricultural food grain production after reducing the wastages and seeds assuming that production is used only for consumption purpose.(15) Over the period, food availability has not only been declining in the State but also across regions as the per capita food grain production is declining over the period. The reasons for declining food availability over time and the large variations across regions can be explained by examining productivity that in turn depends on various exogenous and endogenous factors. To begin with, trends in per capita food grain production across regions have been estimated by taking into account the entire population that includes all age groups. (16) In the State, per capita food grain production is declining gradually. This is because of growth in population exceeding that in the food grain production in the State. The visitation of drought $s$ and famine over large parts of the State every three to four years indeed worsens the process (17).

\section{Accessibility:}

A positive right to life would imply that the State provides to each and every person, adequate food and other basic necessities, and that it ensures a healthy environment, so that people may live and grow in dignity. Food availability has been declining in various degrees across regions of Maharashtra. However, the state of food security cannot be determined mainly on the basis of supply side indicators, but accessibility to food is a necessary condition and this depends on the purchasing power as also the welfare programmes like supply of subsidized food. Poverty ratio indicates the proportion of population subsisting on food intake below certain norms of calorie intake. 10 poverty ratio is more robust representative of access to food. Income is an important criterion to assess the purchasing power, which is determined by various factors like the type of employment, skill, education and social status. However, household income data on these factors is not readily available. Therefore, poverty has been estimated based on MPCE from NSSO surveys (18) taking official poverty line.(19)

\section{Sustainability:}

Agriculture is directly linked to very many facets of sustainable development, including poverty eradication, sustainable consumption and production, management of natural resources, energy, freshwater, health, education, trade and market access, as well as technology transfer and capacity building. Agriculture is an integral part of the general development system, serving the system as a whole, and being served by it. If the effects of other sections of the development (20)

Systems reduce sustainability, and then sustainability of agriculture is also affected. Agriculture centers on integrated use of natural resources such as soil, water, climate and biological diversity. The integration of agriculture with other aspects of land management and ecosystem conservation is essential in order to promote both environmental sustainability and agricultural production.

The per capita availability of sufficient food has been used to estimate the quantity of pulses and cereals required for per person per year, using the norms recommended by the Indian Council of Medical Research (22) in 1996. The ICMR recommends $146 \mathrm{~kg}$ of cereals and $25.55 \mathrm{~kg}$ of pulses per year as the food intake norm for a vegetarian adult (21). The availability of the recommended quantity over years will be considered as the sustainable food availability.

\section{Absorption:}

The next element in understanding food security is food absorption or utilization. The ability of a person does not depend on the characteristics of goods (22); however, better absorption capacity together with other input $\mathrm{s}$ improves the nutritional status. For example, frequent diseases and inadequate health care facilities result in deteriorating nutritional status, particularly among children, as they are the most vulnerable. So Even if there is availability as well as access to food, there is no guarantee of adequate absorption or nutrition, especially since, nutrition depends on many other factors such as the condition of pregnant women, breast feeding, health 13 factors, hygie ne, drinking wate $r$, sanitation, etc. In this section we look at the performance of both access to food and nutritional indicators. Therefore, the nutritional status of childre $n$ has been taken as an indicator for examining the 
absorption capacity as well as the health status

Table 1: Indicators of Food Security

\begin{tabular}{|l|l|l|l|}
\hline Sr. No. & Indicators & Description Variables & Data Sources \\
\hline 1 & $\begin{array}{l}\text { Availability } \\
\text { of food }\end{array}$ & $\begin{array}{l}\text { Indicates food supply through } \\
\text { food production, import and food supply through } \\
\text { Government agencies }\end{array}$ & $\begin{array}{l}\text { Total and per capita Food } \\
\text { grain production }\end{array}$ \\
\hline 3 & $\begin{array}{l}\text { Accessibility } \\
\text { to food }\end{array}$ & $\begin{array}{l}\text { It implies economic and physical accessibility to } \\
\text { food grains }\end{array}$ & Poverty ratio \\
\hline 4 & $\begin{array}{l}\text { Sustainability } \\
\text { food Stability of } \\
\text { Absorption / } \\
\text { utilization of } \\
\text { Food }\end{array}$ & $\begin{array}{l}\text { Incorporates stability in food grains availability and } \\
\text { continued accessibility over time } \\
\text { measured through the nutritional status of an } \\
\text { individual }\end{array}$ & $\begin{array}{l}\text { Normative level of food } \\
\text { availability over time and } \\
\text { Carrying capacity of } \\
\text { agricultural lands } \\
\text { Nutritional status of } \\
\text { children below six years of } \\
\text { age }\end{array}$ \\
\hline
\end{tabular}

\section{Conclusions:}

In this paper we have examined regional disparities in concern to Beed district's economic, agricultural, social, industrial and human resource development in present scenario, which indicates;

- Poverty and food insecurity is greater in rain fed and dry land areas. Small farms can be helped in increasing productivity by having access to extension services and better water management. Sustainable agriculture should be the focus of interventions.

- Local knowledge and local seeds can be used for biodiversity. Organic farming can also be encouraged to protect the environment and generate higher incomes for small farmers.

- New and innovative solutions for water management and improving soil fertility

- Focus on tribal areas for sustainable agriculture and on areas severely hit by climate change.

- The problem of malnutrition is the highest in drought prone areas. Higher agricultural productivity and diversification of agriculture can help in raising incomes. Interventions in some of the programmes like ICDS and midday meal schemes can improve nutrition in marginal and tribal areas.

- In order to improve delivery systems in food based programmes the re is a need to strengthen programmes like ICDS with the conve rgence of several de partments.

- Micro nutrient programme is another area of intervention. For example, Vitamin A tablets alone have prevented many deaths. Vitamin A and food fortification like salt iodization are an integral part of food security programmes.
- Due to changes in consumption patterns, demand for fruits, vegetables, dairy, meat, poultry, and fishery products has been increasing. There is a need to increase crop diversification and improve allied activities.

- Access to food can be increased through employment due to growth in labour intensive sectors and/or through social protection programmes.

- There is a needs for multi-disciplinary approach covering diet diversification including micronutrients, women's empowe rment, education, health, safe drinking water, sanitation, and hygie ne.

- To improve food and nutrition security. NREGS and self-employment programmes can also increase access to food and nutrition.

- Nutrition improvement should combine a rights-based approach and nutrition education. But Nutrition education is more important than legal rights as all human rights need not necessarily be legal rights.

- The most important of all, It has been recognized that better governance is very important for effective functioning of foodbased programmes. Social mobilization, community participation and decentralized approach are also necessary in this context.

\section{References:}

1. WECD, 1987: Food 2000: Global Policies for Sustainable Agriculture. Rep. to the World Commission on Environment and Development. Zed Books Ltd., London.

2. Swaminathan, M.S., 1986: Building national and global nutrition security systems. In: Global Aspects of Food Production, Swaminathan, M.S. and Sinha, S.K. (Eds.), Tycooly International, London, 417-449. 
3. "Empower Poor.Com". Empower Poor.Com.

4. Srinivasan, S.. "Marathwada Profile". Rediff.com.

http://www.rediff.com/election/2004/oct /06maha1.htm. Retrieved 2007-02-26.

5. Kamdar, S. and Basak, A.. "Beyond the Human Development Index, Preliminary Notes on Deprivation and Inequality" (PDF). Mumbai University. http://www.mu.ac.in/economics/File60 Sa ngitawp 1 .pdf. Re trie ved $2007-02-27$.[dead link]

6. "Gazetteers Department of Beed district". maharashtra.gov.in (Government of Maharashtra).

http:/ / www.maharashtra.gov.in/english/ga ze tteer/Beed/ind_intro.html. Retrieved 2007-02-27.

7. ^ "IndianNGOs.com". IndianNGOs.com. http:/ / www.indianngos.com/dis tricts.beed about.htm. Retrieved 2007-03-01. [dead link]

8. "IndianNGOs.com". IndianNGOs.com. Archived from the original on 2007-03-09. http:/ / web .archive.org/web/200703090056 16/http:/ / www.indianngos .com/issue/edu cation/districts/beed.htm. Retrieved 2007 03-01.

9. http://indiacurrentaffairs.org/india-oneday-in-a-cattle-camp-women-and-droughtin-maharash tra-sameena-dalwai/

10. http:// newindianexpress .com/magazine / ar ticle 1491716 .ece

11. http://www.jagranjosh.com/generalknowledge/rural-deve lopment-programmes1322477140-1

12. http://www.midday.com/news /2013 / apr/01 0413-ngoconce rned-ove r-trafficking-of-girls-fromdrought-hit-maharashtra-news national.htm

13. International Organization of Migration (IOM). (2003). Labor migration in Asia: Trends, challenges and policy responses in countries of origin. Ge neva: Author.

14. Indira Gandhi Institute of Development Research, Mumbai August 2011. Climate Change, Rural Livelihoods and Agriculture (focus on Food Security) in Asia-Pacific Region.http://www.igidr.ac.in/pdf/publicati on/WP-2011-014.pdf
15. The availability of food grains has advantages over food grain production because it is measured based on the required food intake norm for the adult population. Adult population is the population of 15 years of age and above, whereas population be low 15 years of age is the pre-adult or child population.

16. Per Capita Food grain Production has been estimated based on the proportion of total food grain production to total population in a given region. The size of population for each year between two census years is derived using exponential method. In order to estimate Per Capita Food grain Availability across regions, the population of Mumbai Sub-urban and Gr. Bombay/Mumbai is excluded from the estimation because the population in these districts does not depend on own produced food grains.

17. DHMJ Drought Forum (2008). Combating Drought in Maharashtra. Published by Info Change for the

18. Poorest Areas Civil Society (PACS) Programme supported by the UK Government's Department

19. for International Development (DFID).

20. The NSSO has been conducting large scale surveys every five years on a regular basis since 1973-74 for collecting information on consumption expenditure, known as "Quinquennial Survey".

21. The official poverty line for rural Maharashtra was' $146.21, ` 334, ` 478$ and for urban Maharashtra 328.56, 539.71 and 637 for the period of 1993-94, 199900 and 2004-05, re spectively.

22. Food Security in Maharashtra: Regional Dimensions The Institute for Social and Economic Change, Working paper 264, Bangalore Nitin Tagade ISBN 978-81-7791120-6

23. ICMR (1996). Some common Indian Recipes and other Nutritive Value. Hyderabad: National Ins titute of Nutrition.

24. Sen, Amartya (1985). Commodities and Capabilities. Professor Dr P Hennipman Lectures in Economics. New York: Oxford University Press. 